\title{
Human autoantibodies react with glutamic acid decarboxylase antigen in human and rat but not in mouse pancreatic islets
}

\author{
L. A. Velloso ${ }^{1}$, O.Kämpe ${ }^{1}$, D.L. Eizirik ${ }^{2}$, A.Hallberg ${ }^{1}$, A. Andersson ${ }^{2}$ and F.A. Karlsson ${ }^{1}$ \\ ${ }^{1}$ Department of Internal Medicine, University Hospital, and \\ ${ }^{2}$ Department of Medical Cell Biology, Uppsala University, Uppsala, Sweden
}

\begin{abstract}
Summary. The presence of one of the major targets for autoantibodies in Type 1 (insulin-dependent) diabetes mellitus, the enzyme glutamic acid decarboxylase, was studied in human, rat and mouse pancreatic tissue using immunoprecipitation and immunohistochemical techniques. Immunoprecipitation of glutamic acid decarboxylase was attempted with lysates of [ $\left.{ }^{35} \mathrm{~S}\right]$-methionine-labelled rat or mouse pancreatic islets using two different glutamic acid decarboxylase antisera, one mouse monoclonal antibody raised against the $65 \mathrm{kDa}$ isoform of the enzyme, sera from six patients with Type 1 diabetes, one patient with stiff-man syndrome and sera from 19 non-obese diabetic mice. The same sera were used for immunoperoxidase staining of cryosections of human, rat or mouse pancreas. Using patient sera glutamic acid decarboxylase was detected by immunoprecipitations from isolated rat islets but not from islets of five different mouse strains tested, including the non-obese diabetic mouse. When using the non-obese diabetic mouse sera, glu-
\end{abstract}

tamic acid decarboxylase could not be detected in either rat or mouse tissue. Immunoperoxidase staining demonstrated high levels of glutamic acid decarboxylase in human and rat pancreatic islets but low levels in mouse islets. Direct measurements of enzyme activity showed glutamic acid decarboxylase to be present in mouse islets at a level of about $40 \%$ of that in rat islets, and subsequent Western blot analyses indicated that mouse islets express the $67 \mathrm{kDa}$ isoform, whereas in rat islets both the 67 and $65 \mathrm{kDa}$ isoforms are present. The species difference at the level of one of the major islet cell autoantigens in Type 1 diabetes thus indicates that human or rat and mouse islets, respectively, express immunologically distinct forms of glutamic acid decarboxylase and differ in their way of regulating the enzyme production.

Key words: Type 1 (insulin-dependent) diabetes mellitus, autoantigen, glutamic acid decarboxylase, NOD mouse, islets of Langerhans.
The destruction of insulin-producing beta cells precedes the clinical onset of Type 1 (insulin-dependent) diabetes mellitus and is believed to be caused by autoimmune mechanisms [1]. These mechanisms include lymphocytic infiltration of islets and the formation of autoantibodies. Sera of patients with recent-onset Type 1 diabetes often contain antibodies recognizing a $64 \mathrm{kDa}$ protein [2], recently shown to be identical to the gamma-aminobutyric acid (GABA)-synthesizing enzyme glutamic acid decarboxylase (GAD) [3]. Apart from GAD, sera of patients with Type 1 diabetes also react with other islet cell antigens. Thus, an antigen of presumed glycolipid nature [1], islet cell surface antigens [4], as well as a "diabetes associated protein" [5] have been described. The molecular characteristics of these antigens, which appear unrelated to GAD, remain unknown. A commonly used animal model for Type 1 diabetes is the non-obese diabetic (NOD) mouse, a strain in which the animals become diabetic in varying frequences in different colonies be- tween 80 and 200 days of age [6]. Although there is a female preponderance of disease, this model is generally regarded to be more representative of the human disease than the $\mathrm{BB}$ rat model [1]. It would therefore be of interest to examine the regulation of GAD-synthesis and the development of diabetes in the NOD-mouse. Autoantibodies to a $64 \mathrm{kDa}$ protein have been reported previously in sera from NOD mice using labelled mouse islet cells as the antigen source [7]. However, we unexpectedly failed in our initial immunoprecipitation experiments with human sera, to positively identify the doublet of $64 \mathrm{kDa}$ [8] on sodium dodecyl sulphate polyacrylamide gel electrophoresis (SDS-PAGE) from $\left[{ }^{35} \mathrm{~S}\right]$-methionine labelled NOD mouse islets [9]. In the present study we therefore examined the presence of GAD in mouse islets prepared from several different strains, using immunoprecipitation techniques as well as immunoperoxidase staining of mouse, rat and human pancreas sections. To control the reactivity of our different sera, mouse cerebellar tissue 


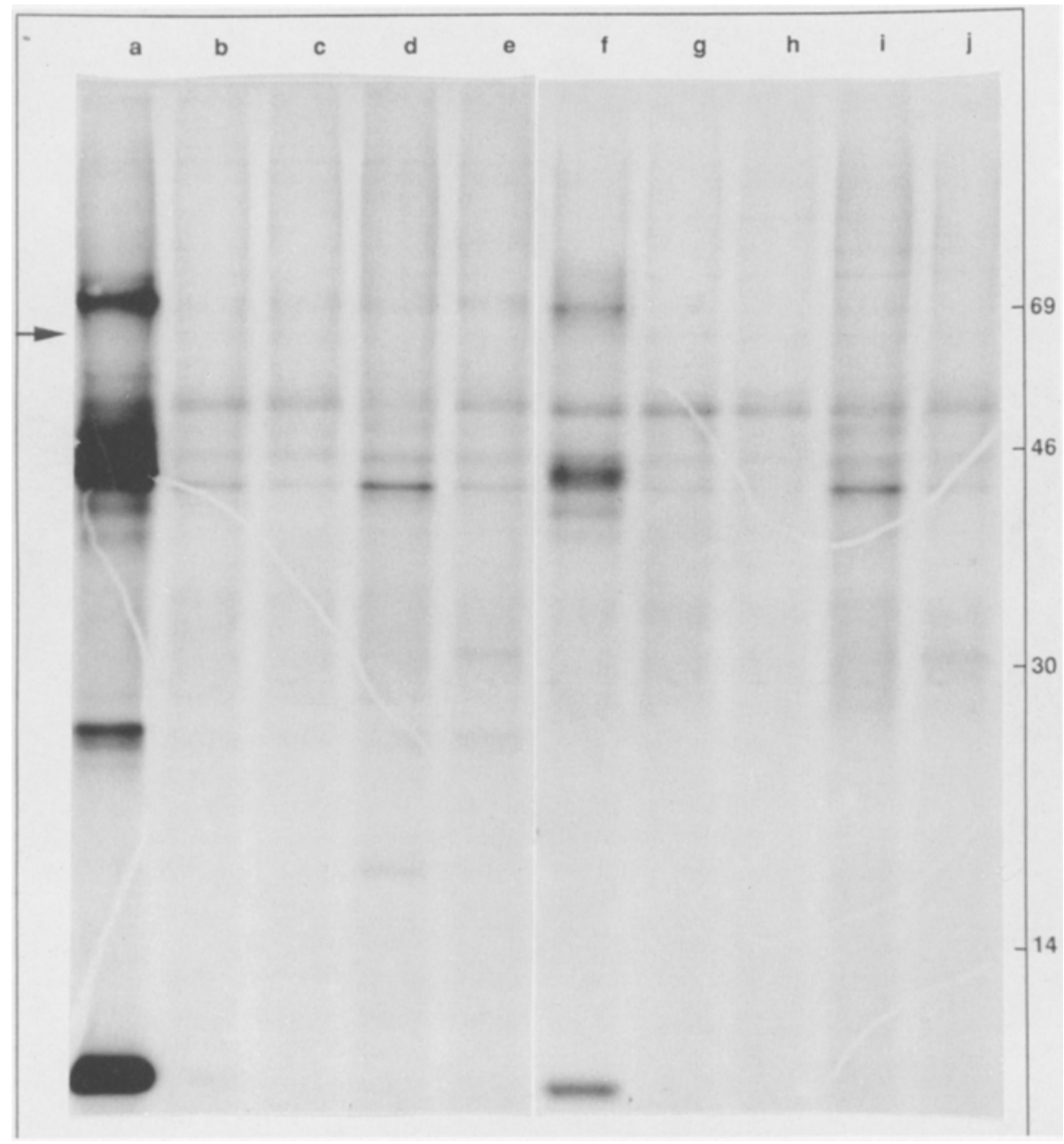

Fig. 1. A fluorograph of sodium dodecyl sulphate-polyacrylamide gel electrophoresis of immunoprecipitates of [ $\left.{ }^{35} \mathrm{~S}\right]-$ methionine-labelled lysates of NOD (a-e) and NMRI (f-j) mouse islets, respectively. Different sera from patients with newly-onset Type 1 (insulin-dependent) diabetes (b-d and $g-i)$ fail to immunoprecipitate the $64 \mathrm{kDa} / \mathrm{GAD}$-doublet. A rabbit serum against the $M H C$ class I was used as positive control ( $a$ and $f$ ). A serum from a healthy control subject (e and $j$ ) was also included

known to contain GAD [10] was also examined. Further, GAD enzymatic activity was measured in lysates of rat and mouse islets and the possible presence of the two different isoforms, the $67 \mathrm{kDa}$ and $65 \mathrm{kDa}$, first described in experiments with brain tissue [11], was examined by Western blot analysis using islet lysates and isoform specific antibodies.

\section{Materials and methods}

Islets from either mice or rats were manually isolated from collagenase-digested pancreas [12]. The animal strains used were WistarFurth rats, aged 12 to 16 weeks (ALAB, Sollentuna, Sweden), NMRI mice (ALAB), C57BL/6 (ob/ob) and C57BL/6 (+/?) mice, both belonging to a local inbred strain originally obtained from the Jackson Laboratory (Bar Harbor, Me., USA), Balb/c (Bomholtgård, Ltd. Ry, Denmark) and 6- to 8-week-old NOD mice. The NOD mouse colony was established in Uppsala in March 1988 by brother and sister mating of the offsprings from three breeding pairs of inbred NOD mice obtained from the Clea company (Aobodi, Japan). The cumulative incidence of diabetes in the colony at 28 weeks of age is $47 \%$ for the females and $7 \%$ for the males [13]. Isolated islets were either used immediately upon isolation or cultured free floating for 3 days in RPMI-1640 medium (Seromed, Biochrom KG, Berlin, FRG) adjusted to $28 \mathrm{mmol} / \mathrm{l}$ glucose and supplemented with $10 \%$ newborn calf serum (Gibco BRL, Laboratoriedesign, Lidingö, Sweden), $100 \mathrm{U} / \mathrm{ml}$ penicillin and $100 \mu \mathrm{g} / \mathrm{ml}$ streptomycin [14]. For internal labelling, typically 500 isolated islets were incubated with $\left[{ }^{35} \mathrm{~S}\right]$-methionine ( $>800 \mathrm{Ci} / \mathrm{mmol}$, New England Nuclear, Boston, Mass., USA) in methionine-free RPMI 1640 with $28 \mathrm{mmol} / \mathrm{l}$ glucose for $6 \mathrm{~h}$. This glucose concentration has been found to increase the biosynthesis of the $64 \mathrm{kDa} / \mathrm{GAD}$ protein in rat pancreatic islets [8].

After incubation, islets were washed twice in ice-cold RPMI1640 medium without calf serum and subsequently lysed at $4{ }^{\circ} \mathrm{C}$ in $20 \mathrm{mmol} / /$ Tris- $\mathrm{HCl}$ buffer ( $\mathrm{pH} 7.4$ ) containing $0.15 \mathrm{~mol} / \mathrm{l} \mathrm{NaCl}, 1 \%$ (vol/vol) Triton X-100, $2 \mathrm{mmol} / \mathrm{l}$ phenylmethylsulphonyl fluoride and $1 \%$ (vol/vol) Trasylol (Bayer, Leverkusen, FRG). Insoluble material was removed by centrifugation at $100,000 \times \mathrm{g}$ for $60 \mathrm{~min}$ at $4^{\circ} \mathrm{C}$. The lysates were pre-cleared overnight at $4^{\circ} \mathrm{C}$ with pre-immune control serum and subsequently incubated in equal aliquots for $24 \mathrm{~h}$ with the different antisera used. Immunoprecipitates were treated as described [8]. SDS-PAGE was carried out on 9-14\% gradient slab gels according to Blobel and Doberstein [15].

To determine (pro)insulin and total protein biosynthesis, groups of 60 islets were isolated from NMRI mice and Wistar-Furth rats and cultured for $24 \mathrm{~h}$ in RPMI-1640 containing $28 \mathrm{mmol} / 1$ glucose. After this period, duplicate groups of 20 islets each were incubated for $2 \mathrm{~h}$ at $37^{\circ} \mathrm{C}$ in a Krebs-Ringer bicarbonate buffer containing $28 \mathrm{mmol} / \mathrm{l}$ glucose and L-[4.5. $\left.{ }^{3} \mathrm{H}\right]$-leucine (Amersham International, Amersham, Bucks, UK), and the islet (pro)insulin and total protein biosynthesis determined as previously described [13].

Cryostat sections of unfixed Wistar-Furth rat or NMRI mouse pancreas or cerebellar tissue were stored at $-70^{\circ} \mathrm{C}$ before use. Mild fixation was performed at $4{ }^{\circ} \mathrm{C}$ in $50 \%$ (vol/vol) acetone for $30 \mathrm{~s}$ and then in $100 \%$ acetone for $5 \mathrm{~min}$. After air-drying at room temperature the sections were rinsed in phosphate buffered saline (PBS) for $5 \mathrm{~min}$, incubated in $0.3 \% \mathrm{H}_{2} \mathrm{O}_{2}$ for $15 \mathrm{~min}$ and again rinsed in PBS. 


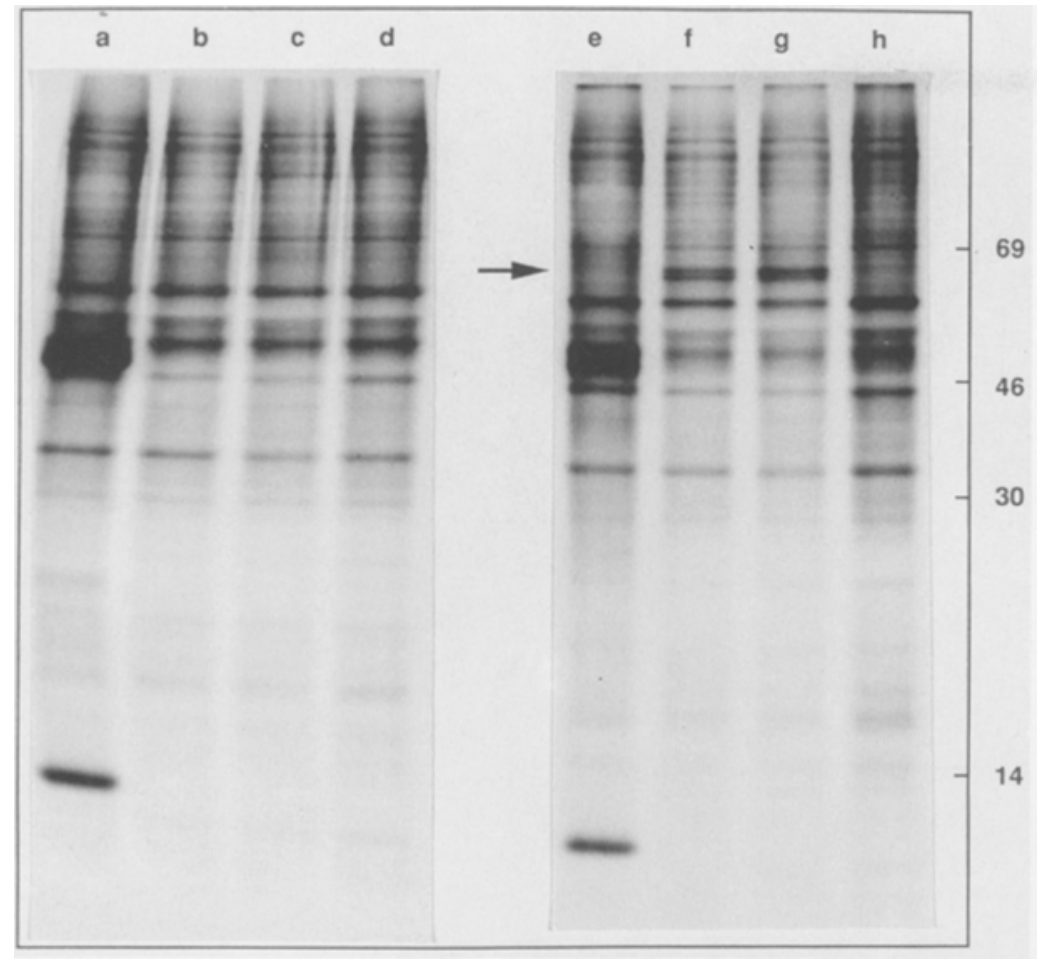

Fig. 2. A fluorograph of sodium dodecyl sulphate-polyacrylamide gel electrophoresis of immunoprecipitates of $\left[{ }^{35} \mathrm{~S}\right]$-methionine-labelled lysates of islets isolated from Balb/c mice (a-d) and Wistar Furth rats $(\mathrm{e}-\mathrm{h})$. Sera from patients with newly-onset Type 1 (insulindependent) diabetes precipitate the $64 \mathrm{kDa}$ doublet in rat ( $\mathrm{f}$ and $\mathrm{g}$ ) but not mouse ( $\mathrm{b}$ and $\mathrm{c}$ ). A rabbit serum against the MHC class I was used as positive control (a and e). A serum from a healthy control person ( $\mathrm{d}$ and $\mathrm{h}$ ) was also included

Incubation with normal rabbit serum for $5 \mathrm{~min}$ at room temperature preceded the incubation with patientsera $(50 \mu \mathrm{l})$ for $24 \mathrm{~h}$ at $4^{\circ} \mathrm{C}$. Following PBS washing, each section was covered with a 1:200 dilution of peroxidase-conjugated rabbit anti-human, anti-rabbit or antisheep IgG antibody (DAKO-immunoglobulins A/S, Denmark) and the incubation was continued for another $30 \mathrm{~min}$ at room temperature. After washing the chromogenic reaction was started by addition of a mixture containing $10 \mathrm{mg}$ 3-amino-9-ethylcarbazol dissolved in $6 \mathrm{ml}$ dimethyl sulphoxide, $50 \mathrm{ml} 0.02 \mathrm{~mol} / \mathrm{NaAc} \mathrm{pH} 5.5$ and $4 \mu \mathrm{l} 30 \% \mathrm{H}_{2} \mathrm{O}_{2}$. The reaction was continued for $15 \mathrm{~min}$ at room temperature. Following washing, the slides were stained with haematoxylin. Cryostat sections of unfixed human pancreas from cadaveric kidney donors were employed, using an indirect immunofluorescence technique, to identify Type 1 diabetic sera with high titres of islet cell antibodies, i. e. sera with more than 80 Juvenile Diabetes Foundation units (JDF-units).

Glutamic acid decarboxylase activity was determined essentially as described $[16,17]$. Freshly isolated islets of Wistar-Furth rats and NMRI mice were washed in PBS and homogenized in a buffer containing $1 \mathrm{mmol} / 1$ 2-aminoethyl isothiouronium bromide (Sigma, St. Louis, Mo., USA), $1 \mathrm{mmol} / \mathrm{l}$ EDTA, $0.025 \mathrm{mmol} / \mathrm{l}$ pyridoxalphosphate (Sigma), pH 7.0. Total protein concentration in the homogenate was determined by spectrophotometry. For the assay, $100 \mu \mathrm{l}$ of the homogenates were incubated in duplicates with $0.375 \mu \mathrm{Ci}$ of $\left[{ }^{14} \mathrm{C}\right]$ glutamic acid $(270 \mathrm{mCi} / \mathrm{mmol}$, Amersham) for $18 \mathrm{~h}$ at room temperature. The released $\left[{ }^{14} \mathrm{C}\right] \mathrm{CO}_{2}$ was absorbed in filter paper soaked in $1 \mathrm{~mol} / \mathrm{l}$ hyamine hydroxide (Sigma) and quantified by liquid scintillation spectrometry.

In Western blot experiments lysates of cultured islets were subjected to SDS-PAGE, blotted onto nitrocellulose paper and incubated with different antibodies. The procedures for running SDSPAGE and performing the immunoblotting were as described elsewhere [18].

Sera from six patients with recent-onset Type 1 diabetes and one patient with stiff-man syndrome were used in the study. Antiserum NIMH 1440 [10], raised in sheep against purified rat GAD, which reacts against both forms of the enzyme with preference for the $65 \mathrm{kDa}$ isoform was a gift from Dr. I.J. Kopin and co-workers at the Laboratory of Clinical Sciences, NIMH, Bethesda, Md., USA. A rabbit antiserum (K2) against feline $\mathrm{GAD} 67 \mathrm{kD}$ a was a gift from $\mathrm{Dr}$.
A. Tobin, UCLA, Los Angeles, Calif., USA [19]. The GAD-6 monoclonal antibody [20] was produced in our laboratory by a hybridoma cell line purchased from the Developmental Studies Hybridoma Bank, University of Iowa, USA. Sera from 19 NOD mice aged 10 to 14 weeks, being 10 females and 9 males, were purchased from Bomholtgård Breeding and Research Centre Ltd., Ry, Denmark. In this colony $70 \%$ of the females and $35 \%$ of the males are diabetic at 15 weeks of age. Rabbit antisera against rat and mouse MHC class I antigens were kindly provided by Prof. L. Rask, University of Agriculture, Uppsala, Sweden.

\section{Results}

\section{Immunoprecipitation of the $64 \mathrm{kDa} / G A D$-protein}

In initial experiments fresh islets were isolated from NOD and NMRI mice in parallel and labelled with $\left[{ }^{35} \mathrm{~S}\right]-\mathrm{me}-$ thionine for $6 \mathrm{~h}$. Three different patient sera with high titres against the $64 \mathrm{kDa} / \mathrm{GAD}$ protein did not precipitate any material in the molecular range of interest (Fig. 1). On the other hand, MHC class I antigens were easily identified, but present in considerably higher amounts in NOD islets than in islets isolated from NMRI mice. Such interstrain variation was not observed in further experiments using strains other than NOD.

Freshly isolated islets from the three other mouse strains C57BL/6 (ob/ob), C57BL/6 $(+/$ ?) and Balb/c, were tested in parallel with Wistar-Furth rat islets for the presence of the $64 \mathrm{kDa} / \mathrm{GAD}$ protein using sera from Type 1 diabetic patients (Fig. 2). The $64 \mathrm{kDa} / \mathrm{GAD}$ protein could only be identified in the rat lysates, whereas equal amounts of MHC class I antigens were present in both mouse and rat islets. Subsequently, serum from a stiff-man syndrome patient as well as the sheep antiserum NIMH 1440 were used on mouse and rat islet lysates, re- 


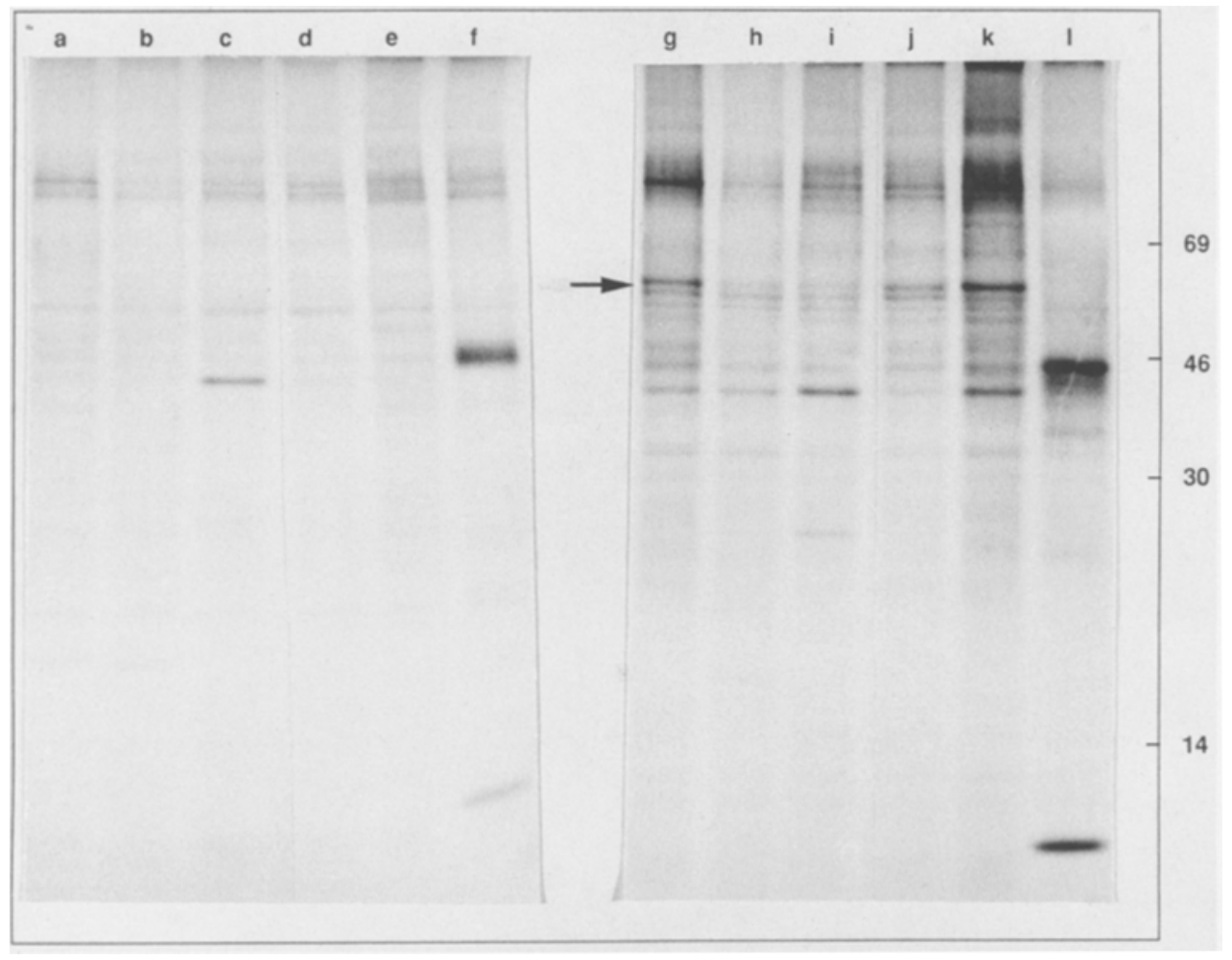

Fig. 3. A sheep serum against purified GAD (e and $k$ ), as well as a serum from a patient with stiffman syndrome (d and j) were used to immunoprecipitate the $64 \mathrm{kDa}$ doublet in $\left[{ }^{35} \mathrm{~S}\right]-$ methionine labelled islet lysates from NMRI mice (a-f) and Wistar Furth rats (g-l). Sera from patients with newly-onset diabetes were also used ( $\mathrm{a}-\mathrm{c}$ and $\mathrm{g}-\mathrm{i}$ ). A rabbit serum against the MHC class I was used as positive control ( $\mathrm{f}$ and $\mathrm{l}$ )

spectively (Fig.3). Whereas the $64 \mathrm{kDa} / \mathrm{GAD}$ protein was easily and reproducibly precipitated from rat islets using the different sera employed here, it could not be identified in any of the mouse strains. Also after high $(28 \mathrm{mmol} / \mathrm{l})$ glucose concentration culture for 3 days we were unable to precipitate the $64 \mathrm{kDa} / \mathrm{GAD}$ protein from the mouse islets with any of the sera used, whereas it could be easily identified in rat islets (not shown).

Immunoprecipitations of $64 \mathrm{kDa} / \mathrm{GAD}$ were attempted using sera of 19 pre-diabetic NOD mice. For that, freshly isolated Wistar-Furth rats and NMRI mice islets were labelled with $\left[{ }^{35} \mathrm{~S}\right]$-methionine and the lysates used in precipitations with sera of all the animals. Controls with sheep antiserum NIMH 1440, rabbit antiserum K2 and mouse monoclonal antibody GAD-6 were positive in precipitating GAD from rat islets but not from mouse islets. None of the 19 mice sera showed precipitation of specific bands in either rat or mouse tissues (not shown).

\section{Biosynthesis of total protein and (pro)insulin}

In order to assess if the observed differences between mouse and rat islets in the immunoprecipitation of the $64 \mathrm{kDa} / \mathrm{GAD}$ protein could be due to a large inter-species difference in protein synthesis, (pro)insulin (PI-I) and total protein biosynthesis (TCA) were determined in mouse and rat islets exposed to $28 \mathrm{mmol} / \mathrm{l}$ glucose. The observed PI-I values were $68 \pm 3 \mathrm{dpm} \times 10^{3} / 20$ islets $\times 2 \mathrm{~h}$ for mouse, and $65 \pm 7 \mathrm{dpm} \times 10^{3} / 20$ islets $\times 2 \mathrm{~h}$ in rat. The TCA values were for mouse islets, $317 \pm 8 \mathrm{dpm} \times 10^{3} / 20$ islets $\times 2 \mathrm{~h}$, and for rat islets $370 \pm 25 \mathrm{dpm} \times 10^{3} / 20$ islets $\times 2 \mathrm{~h}(n=3$, each condition studied in duplicate).

\section{Immunoperoxidase staining of the $64 \mathrm{kD} / \mathrm{GAD}$-protein}

Cryosections of human, rat and mouse pancreatic tissues were immunostained with the sheep antiserum NIMH 1440 using the indirect peroxidase technique. The serum reacted with human (not shown) and rat islets (Fig. 4) with similar intensity. Only very weak staining was found in the mouse islets (Fig. 4). However, in cryosections from rat and mouse cerebellar tissue, strong GADreactivity was found in the Purkinje cell layer of the cerebellum, at similar levels in both species (Fig. 5). A similar staining pattern was obtained when antiserum $\mathrm{K} 2$ was used. Thus, there was a strong staining of rat and mouse brain tissues, less but positive staining of rat islets and no staining of mouse islets (not shown).

\section{Enzyme measurements and Western blots}

Measurements of glutamic acid decarboxylase activity were carried out in five separate experiments with freshly isolated NMRI mouse and Wistar-Furth rat islets. All the experiments were run in duplicates. Rat islets were found to contain about 2.5 times higher enzymatic activity than mouse islets. The means of enzymatic activity from the five experiments were $0.776( \pm 0.138) \mathrm{pmol} / \mathrm{h} \times \mathrm{g}$ protein and $0.326( \pm 0.046) \mathrm{pmol} / \mathrm{h} \times \mathrm{g}$ protein, for rat and mouse respectively.

Subsequently, in immunoblotting experiments, glutamic acid decarboxylase was examined in lysates of cultured rat and mouse islets. Different patterns were seen following incubations with the antisera $\mathrm{K} 2$ and $1440 . \mathrm{K} 2$ is considered specific for the $67 \mathrm{kDa}$ isoform, whereas the 


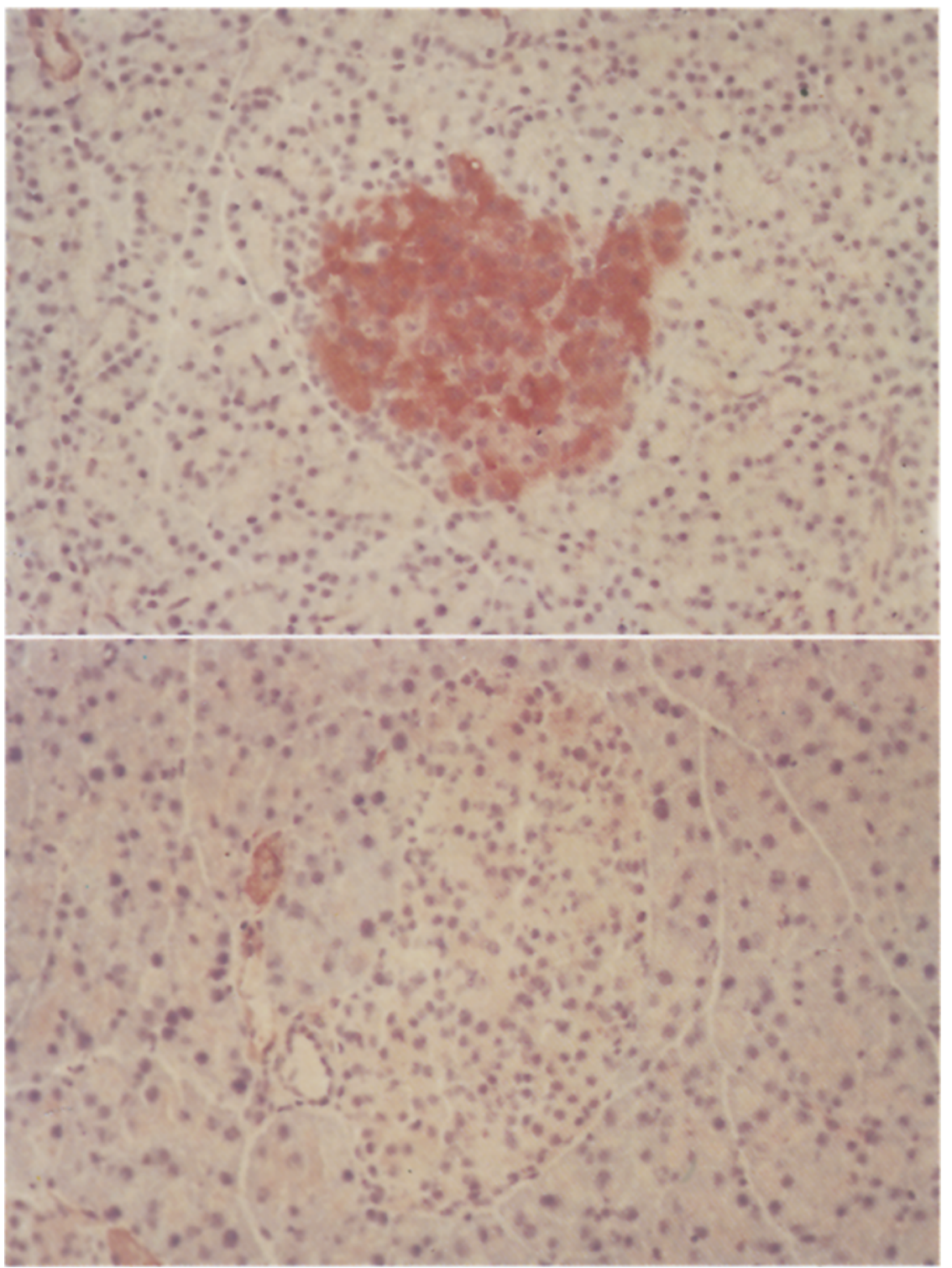

Fig.4. Cryosections of mouse NMRI (lower panel) and rat Wistar-Furth (upper panel) pancreas were stained using an indirect immunoperoxidase technique with a sheep serum raised against purified $G A D$
1440 antiserum is known to react with both the isoforms with a predominance for the $65 \mathrm{kDa}$ component $[10,19]$. The staining intensity of glutamic acid decarboxylase components was considerably weaker in mouse islets than that found in rat islets (Fig. 6). Secondly, the $67 \mathrm{kDa}$ isoform, appearing as a double band, was the only isoform found in mouse islets, whereas in rat islets both isoforms were observed, with the $65 \mathrm{kDa}$ isoform being the more abundant. This species difference was further demonstrated with the GAD-6 monoclonal antibody specific for the $65 \mathrm{kDa}$ isoform, which gave a positive band with rat islets lysates but did not react with any $65 \mathrm{kDa}$ isoform of the mouse islets.

\section{Discussion}

In this study we report a species difference between mice and rats at the level of one of the major autoantigens in Type 1 diabetes, the $64 \mathrm{kDa} / \mathrm{GAD}$ protein in pancreatic islets. In repeated experiments we consistently failed to immunoprecipitate the $64 \mathrm{kDa} / \mathrm{GAD}$ protein in pancreatic islets isolated from five different mouse strains when using sera from six different patients with recent-onset Type 1 diabetes. Precipitations of the MHC class I molecules, used as positive controls in our experiments, showed a relative increase in the NOD mouse islet lysates compared to other mouse strains. This is probably a reflection of an immunopathological process, as suggested by the presence of a mononuclear cell infiltrate around the islets in more than $60 \%$ of the NOD mice at 6 weeks of age [13]. As the experiments for comparison of protein synthesis between rat and mouse islets shrowed no major inter-species difference, the lack of immunoprecipitation of GAD in the mouse islets might be attributed to a very narrow spectrum of epitopes recognized by the patient's antibodies, being able to recognize the rat but not the mouse protein. To further test this, a polyclonal sheep serum raised against purified GAD [10], and expected to have a broader reactivity, was used. Again, a lack of reac- 


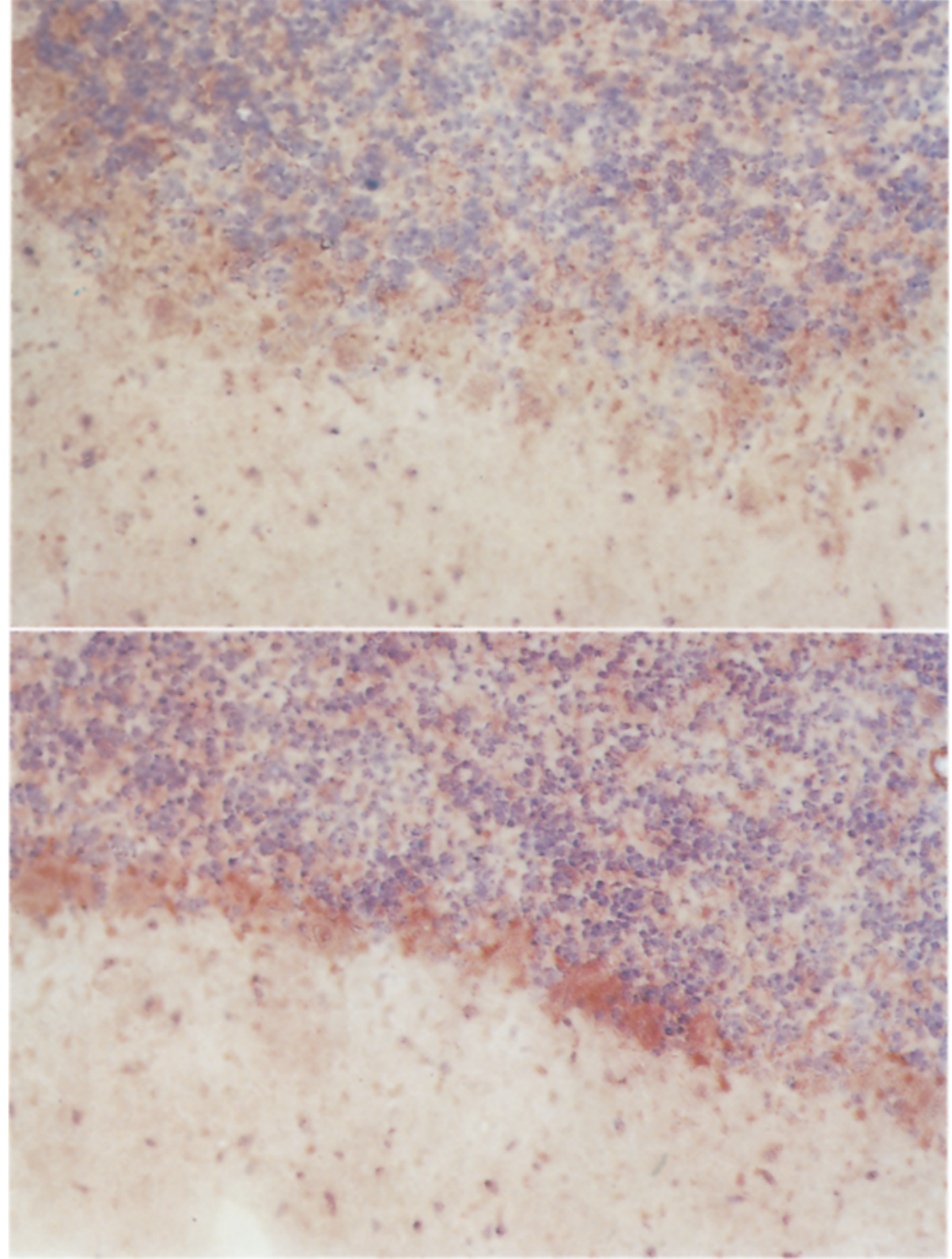

Fig.5. Indirect immunoperoxidase staining of mouse NMRI (lower panel) and rat WistarFurth (upper panel) cerebellar tissue using a sheep serum against purified GAD tivity against $\mathrm{GAD}$ in the mouse islets was observed. Experiments aiming to increase the amount of autoantigen by raising the glucose concentration [8] in the incubation medium, also failed to demonstrate expression of the $64 \mathrm{kDa} / \mathrm{GAD}$ protein in mouse islets. This was also the case in islets from 5-month-old obese hyperglycaemic mice, which are constantly exposed to hyperglycaemia and hyperinsulinaemia [21]. Furthermore, indirect immunohistochemistry revealed a marked species difference, with high reactivity against GAD in human and rat pancreatic islets, but very weak staining of mouse islets. Although polyclonal sheep sera are known to exhibit a broad species cross-reactivity, the question could be raised whether the observed difference was only due to lack of cross-reactivity against the mouse GAD, since the sheep serum used here was indeed raised against purified rat GAD. To test this possibility, sections of mouse and rat cerebellum, known to contain GAD [10], were stained and showed the expected staining of the Purkinje cell layer with equal intensity in both species.
Thus, these data when taken together, suggest that rat and mouse islets differ greatly in their expression of glutamic acid decarboxylase. By the direct enzyme measurements, we detected glutamic acid decarboxylase activity to be present in mouse islets, but at a level considerably lower than that found in rat islets. Such a difference is in accordance with the immunohistochemical studies reported by Gilon et al. [22], who found the immunolabelling of islets considerably less intense in mice than in rats. The lower level of GAD in mouse compared to rat islets is in line with the five-times lower amount of GABA measured in mouse compared to rat islets [23]. Recently, two forms of glutamic acid decarboxylase, GAD $67 \mathrm{kDa}$ and GAD $65 \mathrm{kDa}$, derived from different genes have been described in experiments with brain tissue [11]. With the use of specific antisera directed against the various isoforms, we found by immunoblotting experiments that mouse and rat islets differ in their GAD reactivity. Using the monoclonal antibody GAD-6, which is specific for GAD $65 \mathrm{kDa}$ isoform and reacts with this component of 


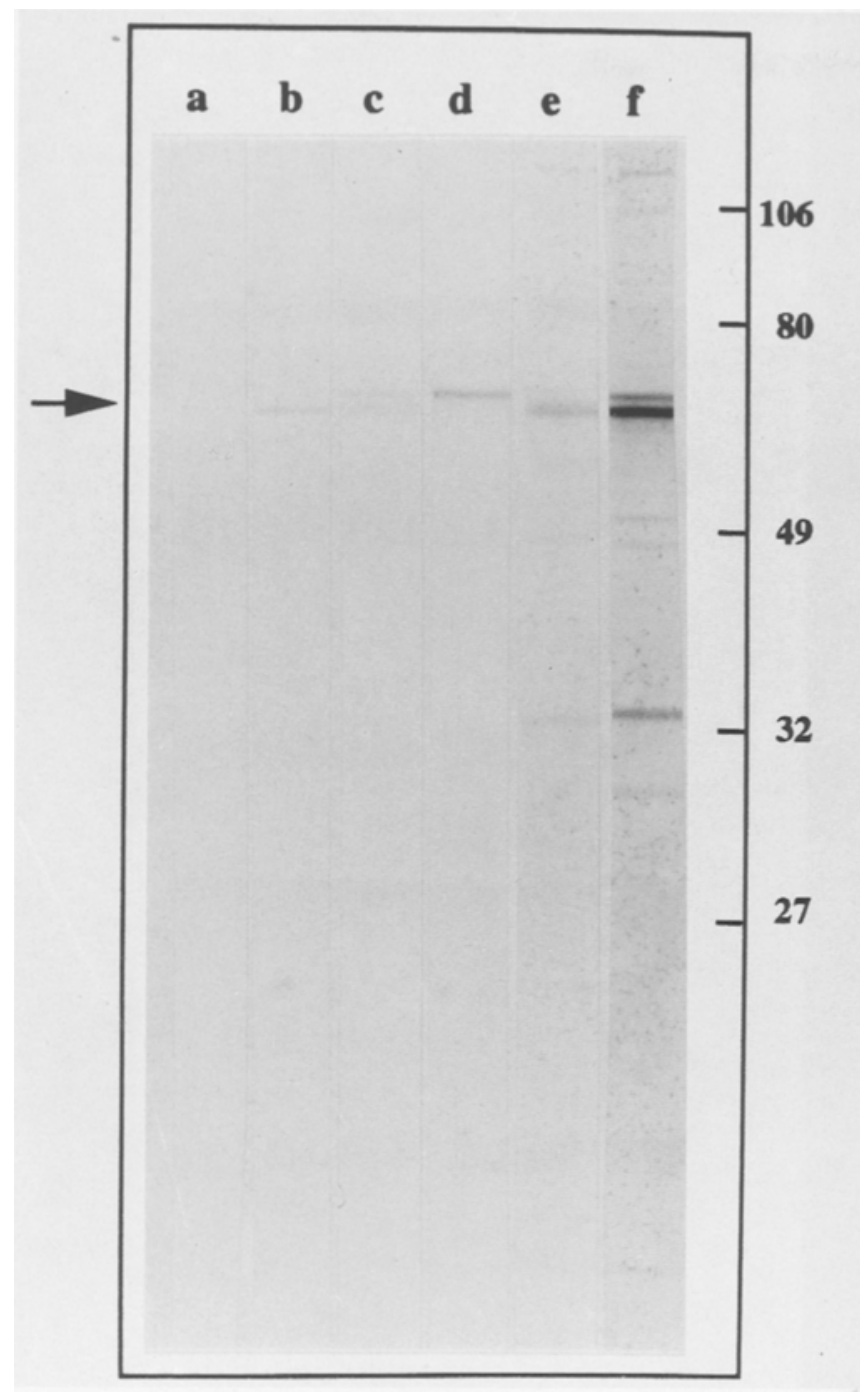

Fig. 6. Western blot analysis of mouse (lanes a, c, and e) and rat (b, d, f) islet lysates reacting with antibodies directed against GAD. The GAD-6 mouse monoclonal antibody, specific for the $65 \mathrm{kDa}$ isoform was used in lanes a and b, the rabbit (K2) antiscrum directed against the $67 \mathrm{kDa}$ isoform in lanes $\mathrm{c}$ and $\mathrm{d}$, and the sheep serum 1440 reacting with both the 67 and $65 \mathrm{kDa}$ isoforms, although primarily with the $65 \mathrm{kDa}$ component, in lanes e and $\mathrm{f}$

rat and human islets [20], we did not detect any reactivity in mouse islets. Further, the two different GAD antisera, 1440 and $\mathrm{K} 2$, reacted with GAD in mouse and rat islets with different staining patterns, which suggested that mouse islets express only the $67 \mathrm{kDa}$ isoform.

In conclusion, this study shows that there is a marked difference between mouse and rat or human islets in their content of GAD, a major target of autoimmune attack in human Type 1 diabetes. Human autoantibodies react primarily with the $65 \mathrm{kDa}$ isoform (Velloso et al. unpublished data), and in human islets only the $65 \mathrm{kDa}$ isoform seems to be expressed $[24,25]$. The present data indicate that in mouse islets the production of GAD is regulated differently, and suggests that in the NOD mouse the expression of the $65 \mathrm{kDa}$ isoform of GAD is not essential for triggering an autoimmune assault to the beta cells. This fact is supported by our negative findings in the immuno- precipitations performed using NOD mouse sera. One might speculate however, that under special conditions, expression of a $65 \mathrm{kDa}$ isoform could be induced in mouse islets as shown by Gerling et al. [26, 27], where Type 1 diabetic patient sera could precipitate a $64 \mathrm{kDa}$ protein from islets isolated from virus infected mice.

Acknowledgements. We thank Ms. M.Eriksson, Ms. A.-C. Sundell, Ms. M. Wic-Lundberg and M. I.-B.Hallgren for excellent technical assistance, Prof. L. Rask for the gift of rabbit antisera against rat and mouse MHC class I antigens, Dr. C. Berne for providing serum from a patient with stiff-man syndrome, and Dr. E. Gylfe for valuable discussion. This study was supported by the Swedish Medical Research Council (19X-4996, 12X-109, 19P-8982, 12X-9886), Torsten och Ragnar Söderbergs Foundation, M.Bergwall Foundation, the Juvenile Diabetes Foundation International the Swedish Diabetes Association, and Novo Nordisk.

\section{References}

1. Castano L, Eisenbarth GS (1990) Type I diabetes: a chronic autoimmune disease of human, mouse and rat. Annu Rev Immunol 8: 437-441

2. Baekkeskov S, Nielsen JH, Marner B, Bilde T, Ludvigsson J, Lernmark $\AA$ (1982) Autoantibodies in newly diagnosed diabetic children immunoprecipitate human pancreatic islet cell proteins. Nature (Lond) 298: 167-169

3. Baekkeskov S, Aanstoot HJ, Christgau S et al. (1990) Identification of the $64 \mathrm{~K}$ autoantigen in insulin-dependent diabetes as the GABA-synthesizing enzyme glutamic acid decarboxylase. Nature (Lond) 347: 151-156

4. Lernmark A, Freedman ZR, Hoffman C et al. (1978) Islet cellsurface antibodies in juvenile diabetes mellitus. $\mathrm{N}$ Engl J Med 299: 375-380

5. Thomas NM, Ginsberg-Fellner F, McEvoy RC (1990) Strong association between diabetes and displacement of mouse anti-rat insulinoma cell monoclonal antibody by human serum in vitro. Diabetes 39: 1203-1211

6. Kolb H (1987) Mouse models of insulin dependent diabetes: lowdose streptozotocin induced-diabetes and nonobese diabetic (NOD) mice. Diabetes Metab Rev 3: 751-778

7. Atkinson MA, McLaren NK (1988) Autoantibodies in nonobese diabetic mice immunoprecipitate $64,000 \mathrm{M}_{\mathrm{r}}$ islet antigen. Diabetes 37: 845-850

8. Kämpe $\mathrm{O}$, Andersson A, Björk E, Hallberg A, Karlsson FA (1989) High-glucose stimulation of $64,000 \mathrm{M}_{\mathrm{r}}$ islet cell autoantigen expression. Diabetes 38: 1326-1328

9. Kämpe O, Hallberg A, Björk E, Andersson A, Karlsson FA (1990) Human diabetic sera react with rat but not mouse islet cells. Immunology of Diabetes, 10th International Workshop, Jerusalem (Abstract)

10. Oertel WH, Schmechel DE, Mugnaini E, Tappaz ML, Kopin IJ (1981) Immunocytochemical localization of glutamate decarboxylase in rat cerebellum with a new antiserum. Neuroscience $6: 2715-2735$

11. Erlander MG, Tillakaratne NJK, Feldblum S, Patel N, Tobin AJ (1991) Two genes encode distinct glutamate decarboxylase with different responses to pyridoxal phosphate. Neuron 7:91-100

12. Howell SL, Taylor KW (1968) Potassium ions and the secretion of insulin by islets of Langerhans incubated in vitro. Biochem $\mathbf{J}$ 108: 17-24

13. Strandell E, Eizirik DL, Sandler S (1990) Reversal of $\beta$-cell suppression in vitro pancreatic islets isolated from non obese diabetic mice during the phase preceding insulin-dependent diabetes mellitus. J Clin Invest 85: 1944-1950

14. Andersson A (1978) Isolated mouse pancreatic islets in culture: effects of serum and different culture media on the insulin production of the islets. Diabetologia 14: 397-404 
15. Blobel G, Dobberstein B (1975) Transfer of proteins across membranes II. Reconstitution of functional rough microsomes from heterologous components. J Cell Biol 67: 852-862

16. Molinoff PB, Kravitz EA (1968) The metabolism of gammaaminobutyric acid (GABA) in the lobster nervous system - glutamic decarboxylase. J Neurochem 15: 391-409

17. Christie MR, Brown TJ, Cassidy D (1992) Binding of antibodies in sera from type 1 (insulin-dependent) diabetic patients to glutamate decarboxylase from rat tissues. Evidence for antigenic and non-antigenic forms of the enzyme. Diabetologia 35: 380 384

18. Winqvist O, Karlsson FA, Kämpe O (1992) 21-hydroxylase, a major autoantigen in idiopathic Addisons's disease. Lancet 339: $1559-1562$

19. Kaufman DL, Houser CR, Tobin AJ (1991) Two forms of the gamma-amino butyric acid synthetic enzyme glutamate decarboxylase have distinct intraneuronal distributions and cofactor interactions. J Neurochem 56: 720-723

20. Chang YC, Gottlieb DI (1988) Characterization of the proteins purified with monoclonal antibodies to glutamic acid decarboxylase. J Neurosci 8: 2123-2130

21. Andersson A, Korsgren O, Naeser P (1990) DNA replication in transplanted and endogenous pancreatic islets of obese-hyperglycemic mice at different stages of the syndrome. Metabolism 38: 974-978

22. Gilon P, Tappaz M, Remacle C (1991) Localization of GAD-like immunoreactivity in pancreas and stomach of the rat and mouse. Histochemistry 96:355-365
23. Okada Y, Taniguchi H, Baba S (1982) High concentration of GABA in the pancreatic islets with special emphasis on $\beta$-cells. Excerpta Medica, Amsterdam, pp 379-386

24. Karlsen AE, Hagopian WA, Grubin CE et al. (1991) Cloning and primary structure of a human islet isoform of glutamic acid decarboxylase from chromosome 10. Proc Natl Acad Sci USA. 88: 8337-8341

25. Björk E, Kämpe $O$, Karlsson FA et al. Glucose regulation of the autoantigen GAD 65 in human pancreatic islets. J Clin Endocrinol Metabol (in press)

26. Gerling I, Chatterjee NK (1990) Autoantigen (64,000) expression in Coxsackie virus B4-induced experimental diabetes. Curr Top Microbiol Immunol 156: 55-62

27. Gerling I, Nejman C, Chatterjee NK (1988) Effect of Coxsakie virus B4 infection in mice on expression of $64,000 \mathrm{M}_{\mathrm{r}}$ autoantigen and glucose sensitivity of islets before development of hyperglycemia. Diabetes 37: 1419-1425

Received: 5 March 1992

and in revised form: 7 September 1992

Dr. L. A. Velloso

Department of Internal Medicine

University Hospital

S-75185 Uppsala

Sweden 